\title{
ANALISIS ANGKA KUMAN UDARA DI RUANG PERAWATAN KELAS III RUMAH SAKIT DKT KOTA BENGKULU
}

\author{
Delly Febriani, NH. Noeraini, Sri Mulyati \\ Poltekkes Kemenkes Bengkulu Jurusan Kesehatan Lingkungan \\ Email :jmkbengkulu@gmail.com
}

\begin{abstract}
Air is one important element in the life of living creatures of the earth and a gas mixture contained in a layer that surrounds the Earth . Air can also act as a means of nosocomial infection . Classrooms III which is the room most at risk of nosocomial infections, where one room within the bed did not qualify and the officer did not use personal protective equipment. The research objective was to determine the total number of bacteria in the treatment room air class III special room 1 male and 2 women's rooms in room sick DKT Bengkulu city. This type of research is qualitative descriptive approach a study that describes the number of total number of bacteria in the air in a Class III hospital treatment DKT city of Bengkulu. Based on the results of the study the total number of air germs in the classroom III consists of one room for boys is $511 \mathrm{CFU} / \mathrm{m} 3$ and women's room 2 is 556 $\mathrm{CFU} / \mathrm{m} 3$. Personal hyigene expected increase for staff and visitors to wash their hands obediently before and after the entrance of the room.
\end{abstract}

Keyword: Air,the total number of number of bacteria,the treatment room air class III at Hospital

\begin{abstract}
Abstrak: Udara adalah salah satu elemen penting dalam kehidupan mahkluk hidup bumi dan suatu campuran gas yang terdapat pada lapisan yang mengelilingi bumi. Udara dapat juga berperan sebagai sarana infeksi Nosokomial. Ruang kelas III yang merupakan ruangan yang paling beresiko terjadinya infeksi nosokomial, dimana salah satu jarak ruangan tempat tidur tidak memenuhi syarat dan petugas tidak menggunakan alat pelindung diri.Tujuan penelitian adalah untuk mengetahui jumlah total angka kuman udara di ruang perawatan kelas III kamar 1 khusus laki-laki dan kamar 2 khusus perempuan di rumah sakit DKT kota Bengkulu.Jenis penelitian adalah kualitatif dengan metode pendekatan deskriptif suatu penelitian yang menggambarkan jumlah total angka kuman di udara pada ruang perawatan kelas III rumah sakit DKT kota Bengkulu.Berdasarkan hasil penelitian jumlah angka kuman udara di ruang kelas III terdiri dari kamar 1 khusus laki-laki adalah $511 \mathrm{CFU} / \mathrm{m}^{3}$ kamar 2 khusus perempuan adalah $556 \mathrm{CFU} / \mathrm{m}^{3}$.Diharapkan meningkatkan personal hyigene bagi petugas maupun pengunjung untuk patuh cuci tangan sebelum dan sesudah masuk ruangan.
\end{abstract}

Kata kunci : Udara, Angka Kuman, Ruang Perawatan Kelas III Rumah Sakit

Angka kejadian Infeksi Nosokomial telah dijadikan salah satu tolak ukur mutu pelayanan rumah sakit. Izin operasional sebuah rumah sakit bisa saja dicabut karena tingginya angka kejadian Infeksi Nosokomial. Bahkan pihak asuransi tidak mau membayar biaya yang ditimbulkan akibat Penelitian yang dilakukan The National Institute of Occupational Safety and Health (NIOSH) terhadap 446 bangunan dan gedung di Amerika, menemukan bahwa terdapat lima sumber pencemar udara dalam ruangan yaitu pencemaran dari alat-alat dalam gedung
(17\%), pencemaran di luar gedung (11\%), pencemaran akibat bahan bangunan (3\%), pencemaran akibat mikroba (5\%), gangguan ventilasi udara (52\%), dan sumber yang belum diketahui $(25 \%)$, yang pernah melakukan surveilans di 55 Rumah Sakit di 14 negara di 4 kawasan (Eropa, Timur Tengah, Asia Tenggara dan Pasifik Barat) menunjukkan rata-rata 8,7 \% dari pasien Rumah Sakit mengalami Infeksi Nosokomial serta lebih dari 1,5 juta orang di seluruh dunia menderita komplikasi infeksi diperoleh di Rumah Sakit. Asia Tenggara dengan besaran kasus $10 \%$ 
menjadi region tertinggi kasus Infeksi Nosokomial. Angka terendah ada di Eropa, dengan jumlah kasus 7,7\%. Di negara maju, kejadian Infeksi Nosokomial diperkirakan 5\% -10\% pasien yang dirawat di Rumah Sakit (WHO, 2004).

Mikroba terdapat di mana-mana di setiap kita, ada yang menghuni tanah, air, dan udara. Studi tentang mikroba yang ada di lingkungan alamiahnya disebut ekologi mikroba. Ekologi merupakan bagian biologi yang berkenaan dengan studi mengenai hubungan organisme atau kelompok dengan lingkungannya. jumlah dan macam mikroorganisme dalam suatu volume udara bervariasi sesuai dengan lokasi, kondisi cuaca dan jumlah orang yang ada. Daerah yang berdebu hampir selalu mempunyai populasi mikroorganisme atmosfer yang tinggi. Sebaliknya hujan, salju atau hujan es akan cendrung mengurangi jumlah organisme di udara dengan membasuh partikel yang lebih berat dan mengendapakan debu. Jumlah mikroorganisme menurun secara menyolok di atas samudera dan jumlah ini semakin berkurang pada ketinggian (altitude) yang tinggi Organisme yang memasuki udara dapat terangkut sejauh beberapa meter atau beberapa kilometer, sebagian segera mati dalam beberapa detik sedangkan yang lain dapat bertahan hidup selama berminggu-minggu, berbulan bulan, bahkan lebih lama lagi. Nasib akhir mikroorganisme yang berasal dari udara diatur oleh keadaan di sekelilingnya (termasuk keadaan atmosfer, kelembaban, cahaya matahari dan suhu), ukuran partikel yang membawa mikroorganismenya terutama kerentanannya terhadap keadaan fisik di atmosfer (Irianto, 2007).

Penyakit infeksi adalah penyakit yang disebabkan oleh mikroba patogen dan bersifat dinamis. Di negara - negara berkembang masih merupakan penyebab utama tingginya angka kesakitan (morbidity) dan angka kematian (mortality) di rumah sakit, dimana infeksi ini lebih dikenal dengan istilah infeksi nosokomial.
Infeksi nosokomial adalah infeksi yang terjadi di rumah sakit dan menyerang penderita yang sedang dalam proses perawatan, terjadi karena adanya transmisi mikroba patogen yang bersumber dari lingkungan rumah sakit dan perangkatnya (Nurvita, Retno dan Budi, 2012).

Sanitasi Rumah Sakit sangat penting untuk dilakukan, mengingat rumah sakit adalah sebagai sarana pelayanan kesehatan untuk masyarakat umum bila sanitasi rumah sakit tidak terjamin dengan baik, maka semakin besar risiko terjadinya ancaman Infeksi Nosokomial pada penderita yang sedang dalam proses asuhan keperawatan. Akibat yang ditimbulkan karena adanya Infeksi Nosokomial cukup luas, baik untuk penderita maupun untuk rumah sakit, antara lain : lama hari perawatan makin panjang, penderitaan bertambah, biaya meningkat. Oleh karena itu, perlu adanya upaya pencegahan dan pengendalian yang sistematis, terencana, dan terkoordinasi yang berkesinambungan. Dengan upaya pencegahan yang lebih mudah dan lebih murah, maka hal-hal yang berkaitan dengan problematika Infeksi Nosokomial dapat dicegah atau dibuat seminimal mungkin (Darmadi, 2008).

Rumah sakit DKT dikenal rumkit TK.IV 02.07.01 Zainul Arifin Bengkulu terletak di jalan kompi lingkar kompi.Berdasarkan survey awal peneliti yang dilakukan pada hari selasa tanggal 25 Januari 2016, di Rumah Sakit DKT ruang pelayanan dan menejemen serta ruang inap kelas I terdiri dari 4 ruangan, kelas II terdiri dari 7 ruangan, VIP utama 1 ruangan, VIP biasa 2 ruangan dan kelas III yaitu 2 ruangan kelas III (Bangsal Wira), terdapat 2 ruangan yang sering dikunjungi oleh pasien yaitu ruang 1 khusus untuk ruangan laki-laki dengan memuat 8 orang pasien begitu juga dengan ruang 2 yang khusus untuk ruangan perempuan juga memuat 8 orang pasien.Penelitian ini bertujuan untuk menetahui total angka 
kuman udara di ruang perawatan kelas III Rumah Sakit DKT Kota Bengkulu.

\section{BAHAN DAN CARA KERJA}

Jenis penelitian yang dilakukan adalah penelitian kualitatif dengan metode pendekatan deskriptif yaitu suatu metode penelitian yang menggambarkan jumlah total angka kuman di udara pada ruang perawatan kelas III Rumah Sakit DKT Kota Bengkulu menggunakan Pemeriksaan Laboratorium (Notoatmodjo, 2010).

\section{HASIL}

Tabel 1. Hasil Total Angka Kuman Udara di Ruang Perawatan Kelas III Rumah Sakit DKT kota Bengkulu

\begin{tabular}{clccc}
\hline No & \multicolumn{1}{c}{ Ruang } & Angka Kuman & NAB & Keterangan \\
\hline 1. & Kamar khusus laki-laki & $511 \mathrm{CFU} / \mathrm{m}^{3}$ & $200-500 \mathrm{CFU} / \mathrm{m}^{3}$ & TMS \\
2. & Kamar khusus perempuan & $556 \mathrm{CFU} / \mathrm{m}^{3}$ & $200-500 \mathrm{CFU} / \mathrm{m}^{3}$ & TMS \\
\hline
\end{tabular}

Berdasarkan hasil pada tabel 1. terlihat bahwa pada ruangan kelas III ruang 1 khusus laki-laki dan ruang 2 khusus perempuan tidak ada yang memenuhi syarat sesuai dengan standar yang ditetapkan oleh Kemenkes RI nomor 1204/MENKES/SK/X/2004.

Tabel 2. Hasil Pengukuran Faktor Penyebab Tingginya Angka Kuman Udara Di Ruang Perawatan Kelas III Rumah Sakit DKT kota Bengkulu

\begin{tabular}{ccccc}
\hline No & Ruang & Suhu & Kelembaban & pencahayaan \\
& & NAB & NAB & 150 LUX \\
\hline 1. & Kamar khusus laki-laki & $31,4^{0} \mathrm{C}$ & $60 \%$ & $100-200$ LUX \\
& & $22-24^{0} \mathrm{C}$ & $45-60 \%$ & 228 LUX \\
2. & \multirow{2}{*}{ Kamar khusus perempuan } & $31,5^{\circ} \mathrm{C}$ & $62 \%$ & $100-200$ LUX \\
\hline
\end{tabular}

\section{PEMBAHASAN}

Berdasarkan hasil penelitian total angka kuman udara di Rumah Sakit DKT Kota Bengkulu di ruang perawatan kelas III masih belum memenuhi syarat. Ruangan yang tidak memenuhi syarat tersebut yaitu terdiri dari 2 ruangan yang memiliki angka kuman udara dengan hasil analisis ruang 1 memiliki angka kuman udara sebesar $511 \mathrm{CFU} / \mathrm{m}^{3}>200-500$ $\mathrm{CFU} / \mathrm{m}^{3}$, kamar 2 sebesar 556 $\mathrm{CFU} / \mathrm{m}^{3}>200-500 \mathrm{CFU} / \mathrm{m}^{3}$ lebih tinggi dibandingkan dengan kamar 1 (khusus laki-laki) karena pada saat penelitian ruangan kamar 1 lebih sedikit pasiennya dibandingkan kamar 2 (khusus perempuan). Hasil analisis univariat diketahui bahwa ruang perawatan Kelas III bangsal terdiri dari 2 ruangan laki-laki dan perempuan dengan persentase $(100 \%)$ tidak ada yang memenuhi syarat, penelitian ini sesuai dengan penelitian Amelia
Gustiana dan Nova Widianingrum (2015) bahwa ruang rawat inap kelas III tidak ada yang memenuhi syarat menurut Kep Men Kes RI. No.1204/MENKES/SK/X/2004 tentang Kesehatan Lingkungan Rumah Sakit.

Hasil pengukuran suhu dan kelembaban ruang kelas III kamar 1 adalah suhu $\left(31,4^{0} \mathrm{C}\right)$ kelembaban $(60 \%)$ dan suhu kelembaban di ruangan kamar 2 suhu $\left(31,5^{\circ} \mathrm{C}\right) \quad$ kelembaban $(62 \%)$ suhu mempengaruhi hasil total angka kuman di udara, suhu diruangan tersebut merupakan suhu optimum untuk perkembangbiakan bakteri. Standar suhu yang sesuai dengan persyaratan kesehatan lingkungan Rumah Sakit adalah $22-24^{0} \mathrm{C}$ dan kelembaban $40-$ $60 \%$ apabila melebihi standar yang telah ditetapkan maka suhu akan mempengaruhi angka kuman udara (KEPMENKES, 2004) begitu juga dengan faktor pencahayaa pada ruangan kamar 1 sebesar ( 150) dan ruangan kamar 2 sebesar (228) standar 
pencahayaan yang sesuai dengan persyaratan kesehatan lingkungan Rumah Sakit adalah 100-200 LUX sehingga hasil kamar 2 yang tidak memenuhi standar yang telah ditetapkan itu juga dapat menyebabkan terjadinya kuman pada udara. Hal ini menunjukakan bahwa total angka kuman udara dapat berperan sebagai sarana infeksi nosocomial (Depkes RI, 2007).

Faktor lingkungan fisik lainnya (pencahayaan, suhu, dan kepadatan hunian) tidak berkorelasi langsung dengan angka kuman tetapi berhubungan dengan kelembaban Faktor animate penularan atau penyebaran kuman mencakuppara petugas rumah sakit dan penderita yang dapat salingmemindahkan kuman. Perilaku tidak sehat dan tidakbersih para petugas, pasien, dan anggota keluarga pasien yang berkunjung ke rumah sakit dapat meningkatkan laju penularan atau penyebaran kuman infeksi ini cenderung berjangkit secara epidemi, muncul dengan eksplosif, dan menyerang orang dalam waktu singkat.

Penyebab tingginya angka kuman udara di ruang perawatan antara lain yaitu suhu, kelembaban, pencahayaaan, jumlah penunggu yang mengalami gangguan kesehatan dan linen yang terkontaminasi serta kurangnya pengetahuan tentang penyakit nosokomialoleh petugas dan pengunjung terutama pada keluarga pasien Pengunjung pasien dapat menjadi salah satu faktor yang dapat menyebabkan pertumbuhan kuman patogen diudara. Karena selain pasien, pengunjung juga dapat membawa bakteri patogen melalui aktivitas yang dilakukan didalam ruangan seperti bersin, batuk dan berbicara serta melakukan aktivitas lain yakni membersihkan ruangan yang dapat

\section{DAFTAR RUJUKAN}

Alumnus, Wikansari, Nurvita, 2012. Pemeriksaan total kuman udara dan staphylococcus aureus di ruang rawat inap rumah sakit $\mathrm{x}$ kota semarang meyebabkan bakteri patogen menyebar ke udara dan kepadatan ruangan atau jumlah orang yang ada dalam ruangan yang dapat berpengaruh pada jumlah bakteri udara, karena penyebaran penyakit dalam ruangan yang padat penghuninya akan lebih cepat jika dibandingkan dengan ruangan yang jarang penghuninya.

Suhu, kelembaban dan pencahayaan yang tidak memenuhi standar yang telah ditetapkan dapat mengakibatkan tingginya angka kuman udara di ruang perawatan, hal ini sesuai dengan penelitian Safriyanto Paulutu (2015) Dengan hasil Kualitas lingkungan fisik yakni suhu, kelembaban, intensitas pecahayaan dari 17 ruangan (100\%) tidak memenuhi standar yang telah ditetapkan. Kontruksi ruang dan bangunan yang tidak memenuhi syarat dapat mempengaruhi kualitas udara secara mikrobiologi dengan indikator jumlah koloni kuman dalam ruangan, proses pembersihan ruangan yang tidak dilakukan dengan baik atau sesuai dengan standar maka akan mempengaruhi jumlah koloni kuman yang ada pada ruangan perawatan tersebut.

\section{KESIMPULAN}

Berdasarkan hasil penelitian dan pembahasan maka dapat disimpulkan dari 2 ruangan kelas III Rumah Sakit DKT Kota Begkulu bahawa :Total angka kuman udara diruang perawatan Kelas III Rumah Sakit DKT Kota Bengkulu pada kamar Ikhusus laki-laki dengan jumlah angka kuman udara adalah (511).Total angka kuman udara diruang perawatan Kelas III Rumah Sakit DKT Kota Bengkulu pada kamar 2 khusus perempuan jumlah angka kuman udaran adalah (556).

Fakultas Kesehatan Masyarakat UNDIP.http:/download.portalgar uda.org/article.php? article $=7391$ 
$2 \& v a l=4700$. Diunduh 01 Februari 2016

Darmadi, 2008, infeksi nosokomial, Salemba medika, Jakarta.

Depkes RI. 2003 tentang kewaspadaan standar infeksi nosokomial. http:/Digilib.unimus.ac.id/download.p $h p ? i d=7786$.

2007. Pedoman pencegahan, penanggulangan dan penularan infeksi nosokomial di ICU. Jakarta

Gillespie, Stephen. 2009at a Glance Mikrobiologi/medis dam infeksi, Erlangga, Jakarta.

Irianto Koes. 2007. Mikrobiologi, menguak dunia mikroganisme, Yrama Widya, Bandung.

Krisno, 2011, Faktor lain yang mempengaruhi infeksi nosokomial. http:/Klikharry.com/2006/12/21/infeksi nosokomial/.

M. Tahir Abdullah, Buraerah Abdul Hakim,2011, Lingkungan fisik dan angka kuman udara ruangan di rumah sakit umum haji makassar, Sulawesi Selatan,http:/jurnalkesmas.ui.ac.id/ind ex.php/kesmas/article/viewFile/128/12 9 ,

Jurnal Kesehatan Masyarakat Nasional Vol. 5, No. 5, April 2011

R. Suhartati, Elyza Nur Faidah, 2014, Identifikasi bakteri oxacillin resistant staphylococcus aureus (orsa) pada ulkus penderita diabetes mellitus di ruang perawatan bedah rumah sakit umum daerah (rsud) tasikmalaya.

Sofiana Liena, Wahyuni Dwi, 2014,Pengaruh sterilisasi ozon terhadap penurunan angka kuman udara di ruang rawat inap di rumah sakit umum PKU Muhammadiyah Bantul.http:/journal.uad.ac.id/index.p hp/KesMas/article/view/1553/pdf_35.

Safriyanto Paulutu, sunarto kadir, sirajuddien bialangi, 2015. Pengaruh lingkungan fisik dan jumlah pengunjung pasien terhadap keberadaan staphylococcus aureus pada udara ruang rawat inap kelas II dan III RSUD Toto Kabila.

http:/kim.ung.ac.id/index.php/KIMFIK K/article/view/10875.

UU nomor 44,2009. Tentang rumah sakit. www.dikti.go.id/files/UU-442009rumah sakit. Diunduh 04 februari 2016.

Widianingrum Nova, 2015. Analisis total kuman udara di ruang rawat inap

Di rumah sakit rafflesia Kota Bengkulu. Poltekkes Kemenkes Bengkulu Jurusan Kesehatan Lingkungan. 